ВЕСТНИК БУРЯТСКОГО ГОСУДАРСТВЕННОГО УНИВЕРСИТЕТА.

Научная статья

УДК 94(47)(1-21)

DOI: $10.18101 / 2305-753 X-2021-4-24-32$

\title{
НОВОУЧРЕЖДЕННЫЕ ГОРОДА РОССИИ В КОНЦЕ XVIII ВЕКА
}

\section{(c) Четырина Наталья Аркадьевна}

научный сотрудник кафедры истории и теории политики, Московский государственный университет им. М. В. Ломоносова Россия, 119192, г. Москва, Ломоносовский проспект, 27 nchetyrina@yandex.ru

\begin{abstract}
Аннотация. В статье рассматриваются изменения в жизни новоучрежденных городов России конца XVIII в. применительно к таким параметрам как состав населения, структура управления, специфика самоуправления, перепланировка и благоустройство, хозяйственная жизнь и народное просвещение. Сопоставимый материал о состоянии городов империи на рубеже веков взят из «Словаря географического Российского государства», изданного Афанасием Щекатовым в начале XIX в. В ходе сопоставительного анализа автор приходит к выводу о том, что изменение юридического статуса поселения становилось исходной точкой в процессе формирования и развития особых городских форм жизни, прежде всего сословно-правовых, геральдических, экономических, а также административно-управленческих и самоуправленческих, связанных с внедрением новых селитебных принципов, организации социальной инфраструктуры, способствовал проникновению новшеств в ежедневный быт.
\end{abstract}

Ключевые слова: город, городские сословия, самоуправление, перепланировка.

\section{Для цитирования}

Четырина Н. А. Новоучрежденные города России в конце XVIII века // Вестник Бурятского государственного университета. Гуманитарные исследования Внутренней Азии. 2021. Вып. 4. С. 24-32.

Одной из традиционных проблем в отечественной историографии является история русского города. Российские города XVIII в. отличались по числу и составу населения, по уровню и характеру хозяйственной жизни, по масштабу взаимодействия с округой и интенсивности торговых связей, по укладу жизни, размеру территории, внешнему виду, по преобладающим функциям. В зависимости от места и роли в системе управления страны города делились на столичные, губернские, уездные и безуездные.

Последняя четверть XVIII в. в России была ознаменована масштабным проведением административно-территориальной реформы. Разделение страны на губернии и уезды осуществлялось согласно количеству податного населения, проживавшего на той или иной территории. В губерниях - это 300-400 тыс. душ, а в уездах - 20-30 тыс. душ мужского пола ${ }^{1}$. Всего было создано 48 губерний. Административно-территориальное деление, введенное по областной ре-

\footnotetext{
${ }^{1}$ Полное собрание законов Российской империи (ПСЗРИ). Т. ХХ. № 14392.
} 
форме 1775-1785 гг., просуществовало без значительных изменений вплоть до 1917 г.

С этой реформой связано значительное изменение численности и состава городов России. На смену захиревшим городам появлялись новые, становившиеся административными и хозяйственными центрами своей округи. По подсчетам Ю. Р. Клокмана, к 1785 г., из общего количества городов (не менее 500) 216 являлись новыми [5, с. 202].

ольшая часть этих городов была основана по административным соображениям из числа подходящих сельских поселений. При этом приходилось учитывать удобное для центра уезда расположение поселения, численность, занятия и потенциальные возможности населения. Но, пожалуй, самым главным, было непременное условие принадлежности поселения казне. За все время проведения реформы, сопровождавшейся учреждением новых городов, можно насчитать только три частновладельческих поселения, ставших городами: село Богородицкое Тульской губернии, село Верхнее Воскресенье Костромской губернии и часть села Сычевки Смоленской губернии. Все они были выкуплены казной, не считаясь с ценами за суммы, назначенные владельцами [5, с. 205]. Абсолютное большинство новых городов относилось к числу уездных, некоторые были посадами - городскими поселениями, не являющимися административными центрами, и только один (Пермь) - с самого своего основания получил статус губернского города.

Проследить изменения, происшедшие в новых городах в первые десятилетия после изменения статуса, позволяет изданный Афанасием Щекатовым в начале XIX в. «Географический словарь» [15].

Рассмотрим сословный состав жителей вновь образованных городов. До момента преобразования большинство жителей было крестьянами. Однородный состав дополнялся немногочисленной группой священно- и церковнослужителей, составлявших штат местных церквей и соборов. Обычный порядок разрешал крестьянам записываться в города при наличии соответствующих разрешительных документов и объявленного капитала, т. е. только в купечество, а не в мещанство. Другим обязательным условием была уплата двойных платежей и по купечеству, и по крестьянству в течение длительного времени до следующей ревизии.

Для населения вновь образованных городов порядок менялся. Коренные жители могли записываться в купечество или в мещанство. Кроме того, они освобождались от уплаты двойных податей. Пришлое население этих же городов не имело права выбора сословия и платило двойные подати и другие поборы до очередной ревизии. Но этот порядок соблюдался не всегда. Например, во Владимирской губернии льготы были не предусмотрены ${ }^{1}$. Иначе обстояло дело с населением вновь учрежденного города Кириллова. Без уплаты двойного оклада было разрешено записаться в городские сословия и коренным жителям, и пришлым крестьянам при условии, что последние находились в ведении Коллегии экономии и проживали в поселении собственными домамиㄹ․

\footnotetext{
${ }^{1}$ Полное собрание законов Российской империи (ПСЗРИ). Т. ХХ. № 14392.

2 Там же. № 14500.
} 
Далеко не все крестьяне сразу же решали переходить в новые городские сословия. Во вновь образованном в 1782 г. Сергиевском посаде Московской губернии перешли в купечество - 234, в мещанство - 394, остались в крестьянстве 201 душа мужского пола ${ }^{1}$. В городе Балашове, преобразованном из одноименного села Саратовского наместничества, из общего числа 87 семейств только 19 решили записаться в мещане, остальные - остались в крестьянстве. Похожая ситуация была и в некоторых других новых городах этого региона [5, с. 103].

Следующим важным обстоятельством в жизни новых городов были организация местного управления вообще и самоуправления в частности. Штатное расписание губерний определяло обязательный набор органов местного управления как для уездного города, так и для подчиненного ему уезда. В их числе Управа благочиния во главе с городничим, уездное казначейство, нижний земский суд и т. д. Укомплектование их происходило как путем выбора из числа местных дворян, так и назначением чиновников. Для работы новых учреждений требовались приказнослужители, а нередко, и нижние воинские чины. Их проживание в городе еще более разнообразило состав населения.

Во всех городах, и в уездных, и в посадах, формировались органы самоуправления и создавалась внутрисословная организация.

Срок выборной службы с 1775 г. - составлял три года. По этой причине и выборы на магистратские должности происходили 1 раз в трехлетие. Один раз в три года от купечества и мещанства избирался городской голова - формально самое важное должностное выборное лицо. Фактически же наиболее важным был коллегиальный орган, избираемый на те же сроки - городовой магистрат, состоявший из двух бургомистров и четырех ратманов (для посадов и маленьких городов - ратуша). Другими коллегиальными органами самоуправления были думы - общая градская и шестигласная. Они должны были заниматься решением городских хозяйственных вопросов. Кроме них были избираемые ежегодно сиротский и словесный суды. Ремесленники, объединенные в цехи, также ежегодно выбирали главу Ремесленной управы и в каждом цехе старшин и по два старшинских товарища. Своих старост выбирали купечество и мещанство. Кроме этого избирались сотские и полусотские, ценовщики, депутаты для составления городской обывательской книги.

Процедура выборов отличалась от современной: использовались деревянные шары, а не бумажные бюллетени. Ящик для голосования имел два отделения с отверстиями, одно из которых было белым, другое - черным. Сам ящик прикрывался куском сукна, что обеспечивало тайну голосования. Извлечение из ящика и подсчет шаров происходили публично, в присутствии и избирателей и кандидатов. Шары, обнаруженные в отделении с белым отверстием, считались поданными за кандидата, оказавшиеся в отделении с черным отверстием - против. Голосование происходило за каждого кандидата отдельно, поэтому выборы затягивались по времени. Избранным считался тот кандидат, за которого было подано большее число голосов. Процедурой выборов руководил городской голова. Избирательным (активным) правом обладали только самостоятельные хозяева, но быть избранными могли и их взрослые сыновья при согласии родителей.

\footnotetext{
${ }^{1}$ Российский государственный архив древних актов (РГАДА). Ф. 16. Оп. 1. Д. 537. Л. 32.
} 
Выборы были двухступенчатые, происходили публично под наблюдением представителей власти и результаты утверждались вышестоящими инстанциями. Выдвижением кандидатов занимались дума, городской голова и сами выборщики. К баллотированию могли быть предложены и отсутствующие на момент процедуры персоны. Важным условием была «беспорочность» кандидата, т. е. отсутствие судимостей, наказаний, вексельных претензий, недоимок. Владение грамотой, обязательное для избранного в начале XVIII в., к концу столетия учитывалось не всегда. В Сергиевском посаде неграмотные ратманы вместо подписей удостоверяли документы печатями [7, с. 31-49; 8, с. 50-91; 13, с. 80].

Выборные магистратские должности предполагалось финансировать из государственных сумм, отпущенных на содержание штатных единиц по губернии. Позднее, в 1787 г. сославшись на Городовое Положение 1785 г., сенатским указом жалованье, выплаченное из казенных сумм бургомистрам и ратманам за предыдущий год, было изъято из мирских денег городов и в дальнейшем от государственного финансирования этих должностей отказались [11, с. 53-55].

Работа выборных членов осуществлялась на принципах безвозмездной службы, и была одной из повинностей городского тяглого населения. По этой причине обязательным условием для возможных кандидатов на должности был определенный уровень материального благосостояния. При этом выборные члены ратуши должны были принимать решения в точном соответствии с законом, т. е. без специальной юридической подготовки на практике разбираться в тонкостях законодательства. За его несоблюдение налагались штрафные санкции. Таким образом, в результате в новоучрежденных городах надо было сформировать и организовать функционирование целой системы самоуправления.

Важным аспектом повседневной жизни учреждений было само помещение для заседаний присутствия. Во многих городах вообще не было сколько-нибудь пригодных строений для присутственных мест. Необходимость иметь специальные помещения для ведения делопроизводства учреждениями разного уровня было обусловлено и тем, что в 1717 г. было запрещено принимать посетителей вне канцелярий и вести дела на дому. Обычно для учреждений использовался наемный дом. В некоторых случаях, при удачном стечении обстоятельств горожане могли для этих целей приобрести за общественные деньги собственный дом. Так же и для проживания администрации в одних случаях дома нанимали у местных жителей, в других - возводили новые постройки. В Осташкове Тверской губернии «дом для присутственных мест обывательской от казны нанимаемой каменный 1 , дом для городничего от города выстроенной деревянной 1 ». В городах Ярославской губернии для проживания городничего и уездного казначея построили дома «о двух жильях» в Рыбинске, Мологе и Петровске - каменные, в Пошехони - деревянный на каменном фундаменте [15, Т. 4. с. 305,436 , $925,1113,1276 ;$;. 5. c. 446].

В Тобольске каменное здание магистрата было построено в 1754-1757 гг. Но бывали и другие ситуации. Костромской магистрат был выдворен воеводой из собственного дома, построенного на купеческие мирские деньги. Восстановить справедливость магистрату не удалось. Приютились они где-то в монастырской келье «самой малой и утесненной, от чего в делах немалая остановка». В новоучрежденном городе Кириллове для этих целей арендовались помещения 
в части крепостной стены Кирилло-Белозерского монастыря. В Великих Луках сначала город не имел здания для своих учреждений. В 1790-е гг. наемный дом для магистрата обходился в 29 р. 50 к. Начиная с 1793 г. по предписанию полицейского правления начинается строительство каменного дома для магистрата по присланному из Пскова плану. Только на следующий 1794 г. на это было истрачено 310 р. Сколько всего обошлось это строительство городу - не известно [6, с. $190 ; 12$, с. $41 ; 9$, с. $15 ; 3$, с. $14-15 ; 2$, с. $18 ; 10$, с. $15,8-19]$. К концу столетия во многих городах проблема с помещениями для органов самоуправления в основном была решена. Об этом свидетельствует такой известный источник как «Географический словарь» Афанасия Щекатова. В Воскресенске Московской губернии ратуша была помещена в каменном здании бывшего гостиного дома, в Вышнем Волочке, Осташкове и посаде Погорелое Городище Тверской губернии магистраты (ратуша) находились также в каменных помещениях. В Спасске Рязанской губернии, Лальске Вологодской губернии магистраты помещались в деревянных домах. К моменту ссылки Радищева (1790 г.) в далеком сибирском городке Илимске было 45 домов, церковь и ратуша посреди поселка $[15, \mathrm{~T} .1$, c. 1153,1155 ; T. 3 , с. 1065 ; T. 4 , с. 925 ; T. 5 , c. 1127$]$.

В Сергиевском посаде Московской губернии в конце XVIII в. ратуша несколько раз меняла место своего пребывания. Самые первые заседания проходили в доме купца Андрея Абакшина, найм которого в 1782 г. обходился в 10 р. в месяц. Позднее, ратуша переехала в другой, также наемный деревянный дом. Это был дом приходского священника, в котором были «две горницы с проходными комнатами, с сенми и в них светлица и кладовая чулан» ценою за 30 руб. в год (сумма, вполне сопоставимая с расходами на наем дома для магистрата в Великих Луках). Затем, у Троице-Сергиевой лавры за 50 руб. было куплено ветхое деревянное строение бывшей мужской богадельни близ церкви Вознесения. В 1790 г. после необходимой перестройки и ремонта все присутственные места посада ратуша, сиротский и словесный суды, цеховая ремесленная управа — обрели свое постоянное место.

По мнению Л. Ф. Писарьковой, «внутренняя обстановка учреждений первой четверти XVIII в. мало чем отличалась от приказных интерьеров XVII в. Это сходство сохранялось долго... изо всех углов губернских и областных канцелярий царствования Анны, Елизаветы и даже Екатерины П смотрела старина XVII столетия». Это была «изба, разделенная сенями на две половины. В сенях ждали своей очереди просители. Обязательной принадлежностью каждой канцелярии была судейская камера. В центре ее помещались покрытые красным или зеленым сукном столы... На столах — чернильницы и зерцала... на стене - полки с книгами законов... Интерьер местных учреждений дополняли обитые сукном лавки, стоявшие вдоль стен и стул воеводы с кожаным или суконным тюфяком». В помещении, где происходило заседание «присутствия» считалось желательным иметь портрет главы государства — императора или императрицы в зависимости от ситуации. Наличие зерцала - трехгранной призмы с текстами петровских указов, символизировало торжество законности, порядка, а его отсутствие влекло выговор для виноватых [9, с. $15 ; 14$, с. 22$]$.

Средств из казны на содержание органов самоуправления не выделялось. Все расходы по найму или покупке, содержанию здания, необходимого обслуживающего персонала, на приобретение простейшей мебели (столов, скамей, 
шкафов и др.) и таких элементарных, но необходимых принадлежностей как бумага, чернила, свечи, дрова для отопления - все это было за счет городского тяглого населения. В Сергиевском посаде для этих целей с купечества собиралось по 1 руб., а с мещанства по 62,5 коп. с души мужского пола. Шацкая ратуша в 1786 г. сообщала, что «на расходы города собирается по приговору общества с купцов, мещан... столько денег по раскладке, сколько нужно» ${ }^{12}$ [13, с. 89; 4, с. 469].

Постепенно менялся внешний облик новых городов. Как правило, для них разрабатывались проекты перепланировки с целью упорядочения сложившейся ранее стихийной застройки. Формировался центр, в котором выделялись места для строительства казенных и общественных мест, о которых уже упоминалось ранее. Наиболее предпочтительными для них считались каменные или деревянные на каменном фундаменте дома. Полностью осуществить перестройку за сравнительно короткий срок было невозможно, но начало процессу было положено. В городе Крестцы Новгородской губернии многие дома «выстроены лучшим строением по новому манеру и частию на каменном фундаменте». В Калязине Тверской губернии было «вновь по опробованному (утвержденному H. Ч.) плану построенных каменных 5, деревянных на каменном фундаменте 43, старых не по плану еще построенных каменных 1, деревянных 523, отведено мест под каменные 32 , под деревянные 378». В Тихвине Новгородской губернии «несколько дворянских, купеческих и разночинских домов каменные, а прочие деревянные, выстроенные по плану, лучшим строением и на каменном фундаменте» $[15$, Т. 3 , с. 709,$881 ;$ Т. 6 , с. 214]. Одновременно изменились требования к самой застройке улицы домами - их требовалось возводить фасадами строго по линии улицы.

Многие горожане использовали мероприятия по перепланировке для оформления своих дворовладений в частную собственность. Это право ранее для них было недоступно. Как известно, в сельском поселении права на землю принадлежали всей общине. Перевод поселения в разряд городских приводил к изменению прав жителей, перешедших в купечество и мещанство, на дворовладения в пределах городской черты. Это изменение, не заметное на первый взгляд, имело очень важное значение для развития всего поселения. Теперь жители новоучрежденных городов могли свои дворовладения закрепить за своими семьями, передавать их по наследству в составе недвижимости, давать в приданое дочерям, закладывать, продавать, обменивать и т. д.

Своеобразным аккордом в общей гамме статусных изменений было присвоение поселению важного символа - городского герба. В верхней части герба уездного города в знак территориально-административной подчиненности располагалась эмблема губернского центра.

Во многих городах открывались народные училища, «в коих обучается разного звания юношество Российскому языку и катехизису по изданному к тому методу» со специально подготовленными учителями (Бронницы, Вышний Волочек, Подольск, Никитск, Осташков, Калязин, Корчева и др.); богадельни «для увечных, престарелых и пропитания не имеющих» (Весьегонск, Подольск, Каля-

\footnotetext{
${ }^{1}$ Центральный государственный архив (ЦГА) Москвы. Ф. 73. Оп.1. Д. 431. Л. 109.

2 Центральный государственный архив (ЦГА) Москвы. Ф. 73. Оп. 1. Д. 462. Л. 162.
} 
зин); в некоторых случаях функционировали особые дома «для принятия и воспитания нещасно рожденных младенцев» (Вышний Волочек, Осташков, Калязин, Рыбинск и др.) $[15$, Т. 1, с. $574,1256-1257$; Т. 3, с. 711 ; Т. 4, с. 925, 927, 1193; Т. 5, с. 446]. Народные училища были открыты в Сызрани и Алатыри [1, с. 103107, 167-170].

Хозяйственная жизнь развивалась в разных формах. Купцам и мещанам Мышкина, Петровска, Усть-Сысольска торговля приносила обороты от 4000 до 5000 рублей в год, Лальска - до 20000 р., Пошехони — до 30000 р. Исключительны обороты купечества Рыбинска (до 600000 р.), Осташкова (от 386972 до 450000 р.), Калязина (до 134000 р.). Фабрики и заводы наиболее успешно функционировали в Рыбинске (до 45000 р. в год) и Осташкове (до 110000 р.). Жители занимались разнообразными ремеслами, промыслами, рыбной ловлей, огородничеством, а женщины - рукоделием. Во многих городах продолжали заниматься хлебопашеством (Ардатов, Буй, Духовщина, Ельня, Медынь, Жиздра и др.), а в Усть-Сысольске - наоборот, «по переименованию сего места городом, а жителей в купечество и мещанство, оную землю оставили». Почти во всех городах велась лавочная торговля, были еженедельные базарные дни и ежегодные ярмарки. Одно из исключений составлял Балашов Саратовской губернии, в котором «ни ярмарок, ниже недельных торгов нет» [15, Т. 1, с. 193, 327-328, 593; Т. 2, c. $320,404,491$; T. 3 , c. 711,1065 ; T. 4 , c. $215,457,929-930,1111,1277$; T. 5 , c. $447 ;$ T. 6 , c. 640$]$.

В целом же, момент смены статуса поселения означал начало формирования и развития особых городских форм жизни, которые возможны только при наличии юридического городского статуса. Среди них - формирование новых сословий, городских органов управления и самоуправления, присвоение герба, изменение прав жителей на земельные владения (дворовладения) в пределах городской черты, работы по перепланировке поселения и изменение принципа застройки, организация школ, богаделен и сиротских домов. Другие изменения, происходившие в хозяйственной сфере и в быту, могли происходить как в городском, так и в сельском поселении, но городской статус предоставлял большую свободу для развития разнообразных форм экономики и проникновения новшеств в ежедневный быт.

Лuтература

1. Артамонова Л. М. Общество, власть и просвещение в русской провинции XVIII начала XIX вв. Самара: Изд-во Сам. науч. центра РАН, 2001. 391 с. Текст: непосредственный.

2. Варюхичев А. Г. Слово о граде Кириллове. Архангельск: Сев.-Зап. кн. изд-во, 1990. 217 с. Текст: непосредственный.

3. Дитятин И. И. Столетие С.-Петербургского городского общества. 1785-1885 гг. Санкт-Петербург: Тип. Шредера, 1885. 403 с. Текст: непосредственный.

4. Кизеветтер А. А. Городовое положение Екатерины II 1785 года. Москва: Тип. Имп. Моск. ун-та, 1909. 473 с. Текст: непосредственный.

5. Клокман Ю. Р. Социально-экономическая история русского города. Вторая половина XVIII века. Москва: Наука, 1967. 335 с. Текст: непосредственный.

6. Копцева Т. В. Духовная культура купечества Зауралья (вторая половина XVIII середина XIX в.): диссертация на соискание ученой степени кандидата исторических наук. Екатеринбург, 1997. 284 с. Текст: непосредственный. 
7. Куприянов А. И. Городская демократия: выборы в русской провинции (вторая половина 1780-х — начало 1860-х гг.) // Отечественная история. 2007. № 5. С. 31-49. Текст: непосредственный.

8. Куприянов А. И. Культура городского самоуправления русской провинции. 1780-1860-е годы. Москва: Изд-во Ин-та Российской истории РАН, 2009. 328 с. Текст: непосредственный.

9. Писарькова Л. Ф. Российская бюрократия в эпоху Петра I. Условия службы и характерные черты // Отечественная история. 2004. № 1. С. 18-41. Текст: непосредственный.

10. Пульхеров А. И. Великолуцкое городское общественное управление. 1785-1891 гг. Историческое обозрение. Псков: Псков. губ. стат. ком., 1892. 54 с. Текст: непосредственный.

11. Собрание законов о купцах, мещанах, посадских и цеховых. Санкт-Петербург: Тип. Правит. сената, 1827. XVI. 501. 34 с. Текст: непосредственный.

12. Тарловская В. Р. Провинциальный город и просвещенный абсолютизм // Русская провинция. Культура XVIII-XX веков. Москва, 1993. С. 39-42. Текст: непосредственный.

13. Четырина Н. А. Сергиевский посад в конце XVIII - начале XIX вв. (Посад как тип городского поселения). Москва, 2006. 319 с. Текст: непосредственный.

14. Шепелев А. Е. Чиновный мир России. XVIII - начало XX вв. СанктПетербург: Искусство, 1999. 478 с. Текст: непосредственный.

15. Щекатов А. Географический словарь российского государства. Т. 1. М., 1801; T. 2. M., 1804; T. 3. M., 1804; T. 4. M., 1805; T. 5. M., 1807; T. 6. М., 1808; T. 7. М., 1809. Текст: непосредственный.

Статья поступила в редакцию 12.11.2021; одобрена после рецензирования 03.12.2021; принята к публикации 17.12.2021.

\section{NEWLY FORMED CITIES OF RUSSIA \\ AT THE END OF THE XVIII CENTURY}

\section{Natalia A. Chetyrina}

Researcher of the Department of History and Theory of Politics,

Lomonosov Moscow State University

27 Lomonosovsky Prospekt, Moscow 119991, Russia

nchetyrina@yandex.ru

Abstract. The article examines the changes in the life of newly formed cities of Russia at the end of the XVIII century, such as the composition of the population, the management structure, the specifics of self-government, redevelopment and landscaping, economic life and public education. Comparable material on the state of the empire cities at the turn of the century is taken from the "Dictionary of the Geographical Russian State", published by Afanasy Shchekatov in the early of the XIX century. In the course of a comparative analysis, the author comes to the conclusion that the change in the legal status of the settlement became the starting point in the process of formation and development of special urban forms of life, primarily estate-legal, heraldic, economic, as well as administrativemanagerial and self-governing, associated with the introduction of new residential principles, the organization of social infrastructure, contributed to the penetration of innovations into the daily life.

Keywords: city, urban estates, self-government, redevelopment. 
ВЕСТНИК БУРЯТСКОГО ГОСУДАРСТВЕННОГО УНИВЕРСИТЕТА.

ГУМАНИТАРНЫЕ ИССЛЕДОВАНИЯ ВНУТРЕННЕЙ АЗИИ

For citation

Chetyrina N. A. Newly Formed Cities of Russia at the End of the XVIII Century. Bulletin of Buryat State University. Humanities Research of Inner Asia. 2021; 4: 24-32 (In Russ.).

The article was submitted 12.11.2021; approved after reviewing 03.12.2021; accepted for publication 17.12.2021. 